\title{
GSK3B wt Allele
}

National Cancer Institute

\section{Source}

National Cancer Institute. GSK3B wt Allele. NCI Thesaurus. Code C128885.

Human GSK3B wild-type allele is located in the vicinity of $3 q 13.3$ and is approximately 273

$\mathrm{kb}$ in length. This allele, which encodes glycogen synthase kinase- 3 beta protein, is involved in the negative regulation of glycogen synthesis. 